\title{
Biological productivity and composition of groundnut in relation to seed size
}

\author{
Umar Bolaji Olayinka*, Sherifat Omolabake Owodeyi, Emmanuel Obukohwo Etejere
}

Department of Plant Biology, University of Ilorin, Ilorin Nigeria

${ }^{\star}$ Corresponding author, E-mail: olayinka.bu@unilorin.edu.ng

\begin{abstract}
A field experiment was conducted to evaluate the effect of seed size on seedling emergence, biological yield and proximate composition of groundnut (Arachis hypogaea L.). Matured seeds were graded into three different seed sizes with respect to length. The large seeds were 1.3 to $1.5 \mathrm{~cm}$, medium seeds 1.1 to $1.25 \mathrm{~cm}$ and small seeds were equal to or less than $0.83 \mathrm{~cm}$ in legth. At 10 days after planting, large and medium seed sizes had higher percentage emergence, 54 and $42 \%$, respectively, when compared with small size seeds with $10 \%$ emergence. Growth characteristics such as plant height and number of leaves were higher in plants from relatively larger seeds at various crop stages. Groundnut plants grown from large seed reached their 50\% flowering 3 to 5 days earlier than plants grown from medium and small seed sizes. The results of yield components (seed yield and harvest index) followed a similar pattern to that of growth characters. Composition of the seeds of plants grown from large seeds showed significantly higher moisture (6.82\%) ash (2.72\%), fibre (4.66\%) and carbohydrate content (10.42\%) when compared to seeds harvested from plants established from other seed sizes. Seeds of plants grown from seeds with small size had significantly higher protein $(30.11 \%)$ and fat $(49.10 \%)$ when compared to seeds harvested from plants grown from medium and large seeds. The results of this study revealed that large seed size is associated with improved growth and seed yield with high ercontents of ash, fibre and carbohydrates, but with lower protein and fat.
\end{abstract}

Key words: ash, carbohydrates, fibre, groundnut, productivity, seed size.

Abbreviations: WAP, weeks after planting.

\section{Introduction}

The biological role of seed is to protect and nourish the living cells of embryo until the seedling is established (Kozlowski 1972). As a result, the use of good quality seed is an essential factor for yield increment. The seeds in a seed lot may differ by size, weight and density due to production environment and cultivation practices (Ambika et al. 2014). Seed size is one of the components of seed quality in further affecting crop performance (Adebisi 2004; Adebisi et al. 2011). Therefore, size is a widely accepted measure of seed quality and large seeds have high seedling survival growth and establishment (Jerlin, Vadivelu 2004).

The effect of seed size on crop performance has been found to differ among crops. In wheat, larger seeds tend to produce more vigorous seedlings (Ries, Everson 1973). Germination rate and seedling vigour index values increase with seed size suggesting, the selection of larger seeds for good stand establishment in rice plants (Roy et al. 1996). Vishvanath et al. (2006) observed significantly higher seed quality parameters viz. 100 seed weight, field emergence, seedling length, vigour index with the increase in seed size in french bean. In contrast, in tropical soybean lots with small seed size had maximum seed germination (97\%) and emergence (90\%) while those with large seed size produced the highest seed (88) per plant, pods (54) per plant and seed yield (9.72 g) per plant (Adebisi et al. 2013). In groundnut, seedling vigour grown from shrivelled and small seeds was less than that from large seeds, but more abnormal seedlings were formed from large seeds (34.9\%) than from small and shrivelled seeds (10.6\%) (Sulochanamma, Reddy 2007).

It is apparent that different crops respond to size of seeds in different ways. The aim of the present study was to see how seed size affects biological productivity of groundnut and to provide information on how this factor affects chemcial composition of the harvested seeds.

\section{Materials and methods}

\section{Study site}

Field trials were performed at the Botanical Garden of the University of Ilorin between September and December 2014. The soil of the experimental site was sandy with neutral $\mathrm{pH}$ (6.8). The organic matter content (1.36\%) was moderate with very high nitrogen concentration $(0.65 \%)$. The total rainfall received between September and December was $465 \mathrm{~mm}$. Mean temperature and relative humidity were $34^{\circ} \mathrm{C}$ and $74 \%$, respectively.

\section{Experimental layout and treatment details}

Plot layout followed a completely randomized block design 
with three replications. Gross plot dimensions were $8 \times$ $6 \mathrm{~m}$ with subplot size of $2 \times 2 \mathrm{~m}$. Each subplot was made up of four rows spaced $0.5 \mathrm{~m}$ apart. Plant to plant spacing was $0.1 \mathrm{~m}$. Three different seed sizes designated as large, medium and small were used as treatments. Seed size were grouped by measured length and circumference of each seed using a caliper guage. The large size ranged between 1.3 and $1.5 \mathrm{~cm}$, the medium between 1.1 and $1.25 \mathrm{~cm}$ and smaller had length equal to or less than $0.8 \mathrm{~cm}$. Data on crop morphology was collected from the two inner rows leaving the other two rows as a buffer.

\section{Field operation}

The experimental field was manually cleared with a hoe to remove stump and plant debris. Ridges were made following the plot layout. Two seeds in each of the seed sizes were sown at depth of $0.02 \mathrm{~m}$ and inter-plant spacing of 0.1 $\mathrm{m}$ as described earlier. Prior to planting, seeds were treated with Seedrex $(33 \%$ permethrin $+15 \%$ carbonderzine $+12 \%$ chlorothalonil) at the rate $10 \mathrm{~g}$ of the chemical per $4 \mathrm{~kg}$ of seed to prevent soil-borne diseases and pest attack. Plots were manually weeded at a two-week interval throughout the period of the experiment to reduce weed interference.

\section{Data collection}

At 10 days after planting, emergence counts were made for plants grown from each seed size to determine seed vigour. Morphological parameters such as plant height, and number of leaves were taken at three-week interval. Three plants were chosen from each seed size to determine growth characteristics. Time to reach 50 and $100 \%$ flowering was also calculated. At 12 weeks after planting (WAP) pods were harvested manually and washed in running water to remove soil particles. The pods were then air-dried to $12 \%$ moisture for a period of seven days. Yield components such as number of matured pods per plant, pod weight and seed weight per plant and 100-seed weight were estimated the average for three plants per treatment. Pod and seed yield was expressed in kg per hectare. The harvest index, which is a measure of economic yield over the biological yield, was calculated according to Coombs and Hall (1982):

$$
\text { Harvest index }=\frac{\text { Seed yield }}{\text { Seed yield }+ \text { above ground dry weight }} .
$$

\section{Seed composition}

For plants grown from each seed size, shelled groundnut seeds were ground using hammer mill and analyzed for moisture, ash, crude fibre, crude fat and crude protein following the standard methods of Association of Official Analytical Chemists (AOAC 2000). Moisture content was determined by heating $5 \mathrm{~g}$ of a well mixed ground sample in an oven (Gravity Convection Oven) at $103{ }^{\circ} \mathrm{C}$ for $5 \mathrm{~h}$ to a constant weight. Ash content was determined by incinerating $5 \mathrm{~g}$ of a well mixed ground sample using a hammer mill machine in a muffle furnace at $600^{\circ} \mathrm{C}$ for $3 \mathrm{~h}$ until a light-grey ash was produced.

Crude fibre was determined by extracting $5 \mathrm{~g}$ of the ground sample with hexane for six hours to free the sample of fat. Thereafter, $200 \mathrm{~mL}$ of $1.25 \%$ sulphuric acid was added to $3 \mathrm{~g}$ of the free fat to remove the digestible nutrient in the fat. The resulting mixture was filtered in a Buchner funnel. The residue on the filter paper was placed in a muffle furnace at $600{ }^{\circ} \mathrm{C}$ for $30 \mathrm{~min}$, cooled in a desiccator and weighed.

Crude fat determination was achieved by extraction procedure. Five grams of the ground sample was extracted with $150 \mathrm{~mL}$ petroleum ether as solvent in a Soxhlet extractor at a boiling point of 60 to $80{ }^{\circ} \mathrm{C}$. The extraction was performed for $6 \mathrm{~h}$ with moderate boiling using an elecrothermal heater.

Crude protein was determined by the Kjeldahl method by weighing $1 \mathrm{~g}$ of the ground sample into a Kjeldahl flask. The ground sample was digested with $8 \mathrm{~g}$ of digestion mixture (500 g sodium sulphate, $50 \mathrm{~g}$ copper sulphate, 5 $\mathrm{g}$ selenium) and heated for $1 \mathrm{~h}$ until frothing ceased. The mixture was subjected to distillation by addition of $100 \mathrm{~mL}$ distilled water. Thereafter, $50 \mathrm{~mL}$ of sodium hydroxide was added gently until a precipitate of cupric hydroxide was formed.

The ammonia evolved was collected in a $500-\mathrm{mL}$ conical flask containing $50 \mathrm{~mL}$ of $2 \%$ boric acid solution, $50 \mathrm{~mL}$ of distilled water and three drops of methyl red indicator. The resulting mixture was distilled for $45 \mathrm{~min}$ and titrated against standard $0.01 \mathrm{~N} \mathrm{HCl}$. The nitrogen was converted to crude protein using a multiplication factor of $6.25(\% \mathrm{~N} \times$ 6.25). Carbohydrate was determined by difference. This was achieved by subtracting the sum of moisture, ash, protein, crude fat and crude fibre percentage from 100. All analyses were performed in triplicate.

\section{Data analysis}

Data were subjected to analysis of variance. Least significant difference test at $5 \%$ probability level was used to compare differences among the treatment means (Steel et al. 1997).

\section{Results}

Seedling emergence was affected by seed size as assessed 10 days after planting (Fig.1). Over 50\% of the large seeds had emerged at 10 days, but this was not significantly different from that of medium sized seeds with $43 \%$ emergence. Small sized seeds showed significantly lower emergence (10\%) when compared to the other seed sizes (Fig. 1).

Plant height at different growth stages showed an increasing trend with age of the crop. Significant differences $(p \leq 0.05)$ in plant height were recorded at all crop growth stages except at 6 weeks after planting (WAP). At 3, 9 and 12 WAP, plants developed from large seeds had significantly higher height, followed in decreasing height of plants from medium and small seed sizes (Fig. 2). Leaf production was 


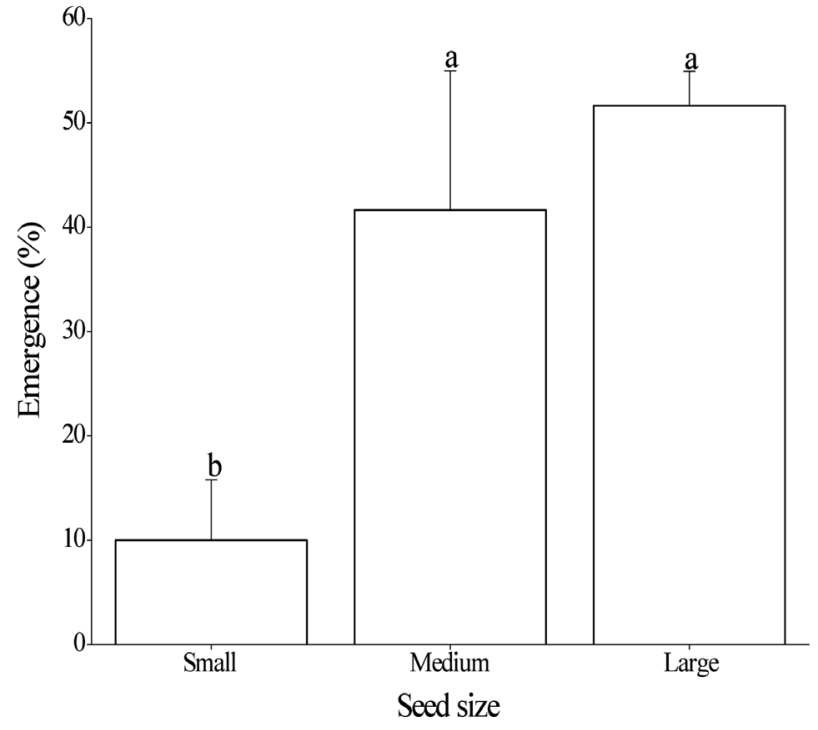

Fig. 1. Percentage emergency of groundnut as influenced different seed sizes. Vertical bars represent standard errors (SE \pm ) of treatment mean.

not significantly affected by seed size at different growth stages, except at 12 WAP (Fig 3). However, higher number of leaves was recorded in plants from large seed, followed by those from medium seed (Fig 3). At all growth stages, lowest leaf production was evident in plants developed from small-sized seeds.

Time to reach 50 and $100 \%$ flowering was significantly affected by differences in seed size (Fig. 4). It took plants developed from small seeds 3 to 5 more days to achieve 50 and $100 \%$ flowering than for plants developed from large and medium sized seeds; this effect was statistically significant. Time to reach 50 and $100 \%$ flowering was not

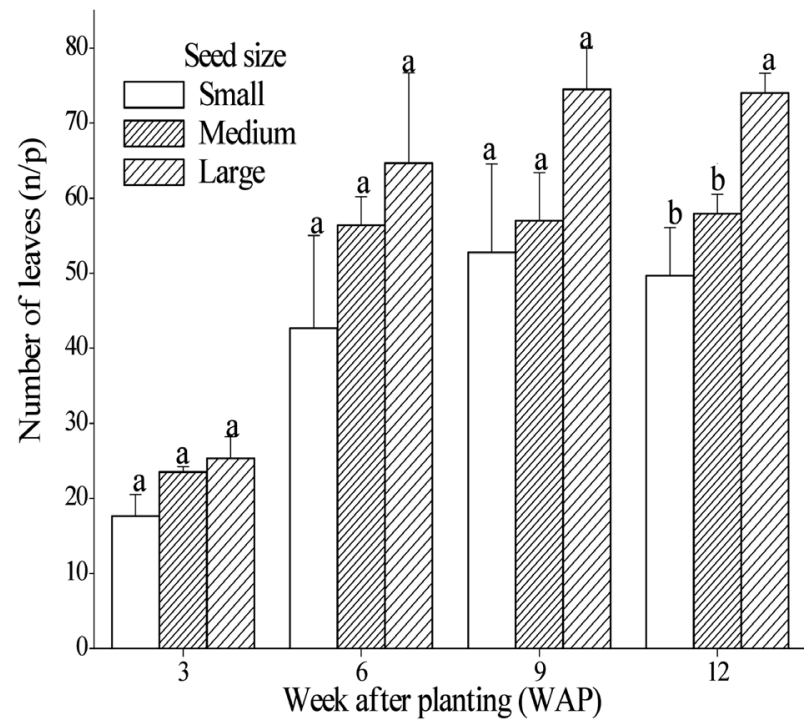

Fig. 3. Number of leaves of groundnut as influenced by seed size. Vertical bars represent standard errors (SE \pm ) of treatment mean.

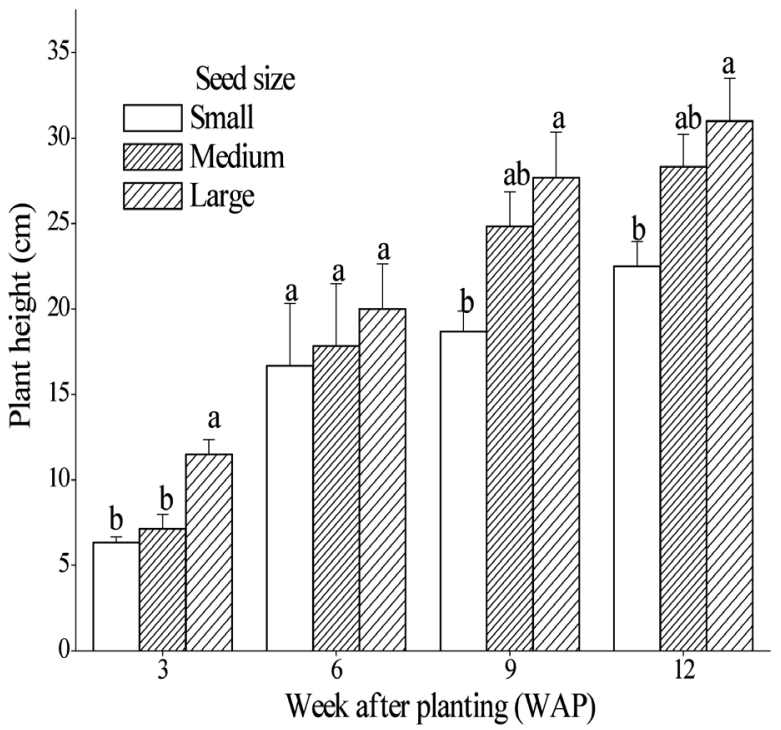

Fig. 2. Plant height of groundnut as influenced by seed size. Vertical bars represent standard errors ( $\mathrm{SE} \pm$ ) of treatment means.

significantly different for plants developed from large and medium seeds. However, plants from large seeds attained more early flowering than from medium seed size (Fig. 4). The results of yield components such as number of matured pods per plant, pod weight per plant, seed weight and 100seed weight were significantly ( $p \leq 0.05)$ affected by seed size (Table 1).

The highest number of pods per plant was recorded for plants developed from large seeds (12.47), followed by medium seeds (7.52) and small seeds (2.87). The results of pod weight per plant, seed weight per plant followed the same trend as for number of pods (Table 1).

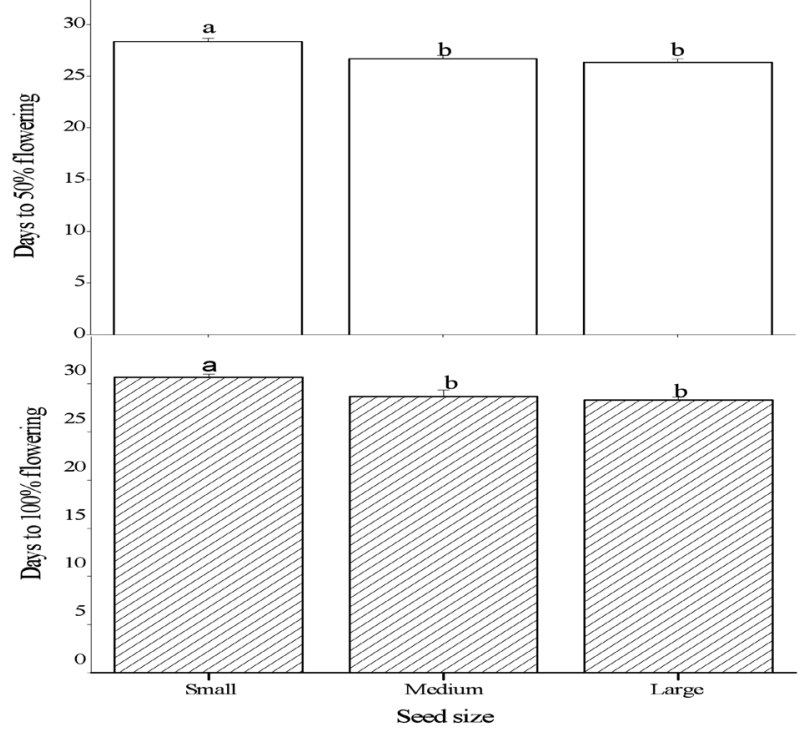

Fig. 4. Days to 50 and $100 \%$ flowering as influenced by seed size. Vertical bars represent standard errors ( $\mathrm{SE} \pm$ ) of treatment mean. 
Table 1. Yield components, yield and harvest index of groundnut in relation to different seed size. Within column means followed by the same letters are not significantly different at $p \leq 0.05$

$\begin{array}{lcccccc}\text { Seed size } & \begin{array}{c}\text { Number of pods } \\ \text { per plant }\end{array} & \begin{array}{c}\text { Pod weight } \\ \left(\text { g plant }^{-1}\right)\end{array} & \begin{array}{c}\text { Seed weight } \\ \left(\text { g plant }^{-1}\right)\end{array} & \begin{array}{c}\text { 100-seed weight } \\ (\mathbf{g})\end{array} & \begin{array}{c}\text { Seed yield } \\ \left(\mathbf{k g ~ h a ~}^{-1}\right)\end{array} & \begin{array}{c}\text { Harvest index } \\ \text { Small }\end{array} \\ 3.33 \pm 0.33 \mathrm{c} & 2.9 \pm 0.2 \mathrm{c} & 1.9 \pm 0.2 \mathrm{c} & 24.80 \pm 3.1 \mathrm{~b} & 195.43 \pm 276 \mathrm{c} & 0.28 \pm 0.03 \mathrm{~b} \\ \text { Medium } & 5.67 \pm 0.33 \mathrm{ab} & 7.5 \pm 0.9 \mathrm{~b} & 5.5 \pm 0.7 \mathrm{~b} & 31.67 \pm 0.3 \mathrm{a} & 363.93 \pm 22.0 \mathrm{ab} & 0.46 \pm 0.04 \mathrm{a} \\ \text { Large } & 8.00 \pm 0.83 \mathrm{a} & 12.5 \pm 1.9 \mathrm{a} & 8.9 \pm 1.4 \mathrm{a} & 35.27 \pm 0.4 \mathrm{a} & 526.30 \pm 89.8 \mathrm{a} & 0.50 \pm 0.01 \mathrm{a} \\ \text { Mean } & 5.67 \pm 0.82 & 7.6 \pm 1.00 & 5.4 \pm 0.3 & 30.58 \pm 1.27 & 360.89 \pm 46.47 & 0.41 \pm 0.03 \\ \text { LSD }(p \leq 0.05) & 3.23 & 4.28 & 3.07 & 6.22 & 151.74 & 0.04 \\ \text { CV }(\%) & 59.70 & 34.34 & 61.75 & 17.46 & 45.83 & 26.99\end{array}$

The 100-seed weight for plants grown from large $(35.27 \mathrm{~g})$ and medium seeds $(31.67 \mathrm{~g})$ did not significantly differ. Significantly lower 100 -seed weight was recorded from small-seeded plants $(24.80 \mathrm{~g})$ (Table 1). Seed yield expressed as kilograms per hectare was generally low across all the seed sizes investigated (Table 1). Significantly higher seed yield was recorded for plants developed from large seed (526.30 $\left.\mathrm{kg} \mathrm{ha}^{-1}\right)$ when compared to these developed from medium (363.93) and small seeds (195.43). Harvest index followed the same trend as that of seed yield, except that large and medium sized seed group did not show a statistically significant difference (Table 1 ).

The results of composition in relation to differences in seed size are presented in Table 2. Seeds harvested from plants derived from large seeds had significantly higher moisture $(6.82 \%)$, crude ash $(2.72 \%)$ fibre $(4.66 \%)$ and carbohydrate (10.42\%) content than these in plants from medium-sized seeds. Lower values were recorded for seeds harvested from plants grown from small seeds.

It should be noted that the percentage moisture, fibre and carbohydrate content recorded for plants developed from medium- and small-sized seeds did not significantly differ (Table 2). In contrast, seeds harvested from smallseeded plants had the highest protein level (30.11\%), compared to that in medium (28.95) and large-seeded (27.95) plants.

Percentage fat content recorded in seeds harvested from plants derived from small seeds (49.10\%) was also significantly higher than that harvested from plants grown from large- (47.40) and medium-sized seeds (48.73). The fat content in seeds from large- and medium-seeded plants did not significantly differ (Table 2).

\section{Discussion}

Growth characteristics of peanut plants, such as crop emergence, plant height and number of leaves were higher in plots where large seeds were sown in comparison to plots with other seed sizes. The higher crop emergence recorded from large seed could be due to the presence of higher amount of carbohydrates, nutrients and faster mobilization of reserves to the growing regions than in medium and small sized seeds. Similar results have been shown by studies with other plant species. Thus, small muskmelon seeds had the lowest percentage germination, emergence and the lowest seedling growth, demonstrating that there is an association between seed physical parameters and seed quality (Nerson 2002). In Alangium lamarckii, large seeds had maximum (76\%) germination followed by medium size (74\%) and small size seeds (59\%) (Ahiwar 2012). In addition, germination parameters are significantly related to seed weight; in lentil genotypes large seeds germinated early and showed better germination than small seeds (Hojjat 2011).

The increased plant height and number of leaves recorded from larger seed over other seed sizes found in the present study agrees with the findings of Nagaraju (2001) who observed higher plant height, number of leaves and stem girth in plants raised by large size seeds (more than $3.0 \mathrm{~mm}$ ) followed by medium (seeds passed through 3.0 $\mathrm{mm}$ sieve) and small seeds (passed through $2.8 \mathrm{~mm}$ sieve).

The results of this study had shown that the effect of seed size did not only affect the groundnut emergence and growth but also affect the yield components and ultimately the seed yield. Plant derived from large seed had higher

Table 2. Composition of groundnut seeds of plants grown from different seed sizes. All parameters are in \%. Within column means followed by the same letters are not significantly different at $p \leq 0.05$

\begin{tabular}{lccccccc} 
Seed size & Moisture & Ash & Fibre & Fat & Protein & Carbohydrate \\
Small & $6.15 \pm 0.08 \mathrm{~b}$ & $2.37 \pm 0.15 \mathrm{c}$ & $4.40 \pm 0.10 \mathrm{~b}$ & $49.10 \pm 0.09 \mathrm{a}$ & $30.11 \pm 0.14 \mathrm{a}$ & $7.87 \pm 0.24 \mathrm{~b}$ \\
\hline Medium & $6.49 \pm 0.13 \mathrm{ab}$ & $2.50 \pm 0.05 \mathrm{~b}$ & $4.61 \pm 0.05 \mathrm{~b}$ & $48.73 \pm 0.05 \mathrm{a}$ & $28.95 \pm 0.19 \mathrm{~b}$ & $8.72 \pm 0.20 \mathrm{~b}$ \\
Large & $6.82 \pm 0.15 \mathrm{a}$ & $2.72 \pm 0.05 \mathrm{a}$ & $4.66 \pm 0.03 \mathrm{a}$ & $47.40 \pm 0.47 \mathrm{~b}$ & $27.95 \pm 0.07 \mathrm{c}$ & $10.42 \pm 0.42 \mathrm{a}$ \\
\hline LSD $(p \leq 0.05)$ & 0.42 & 0.14 & 0.24 & 0.95 & 0.49 & 1.04 \\
CV $(\%)$ & 5.24 & 6.72 & 3.51 & & 1.80 & 3.31 & 13.44 \\
\hline
\end{tabular}


yield due to better vigour and ability to acquire a larger share of plant growth factors than all other seed sizes. The seed yield in terms of kg per hectare was significantly higher in plants derived from large seed. Tawaha and Turk (2004), in a study with field pea, noted that plants produced from heavier seeds had 100-seed weight that was $12 \%$ larger than these produced from lighter seeds. Nagaraju (2001) recorded significantly higher yield and yield traits in sunflower with large seeds (retained over $3.0 \mathrm{~mm}$ sieve) the higher head diameter, number of filled seeds per head, total number of seeds per head, percent seed filling, seed yield per plant and per hectare recorded in plants developed from large seeds followed by these from medium sized seeds (passed through $3.0 \mathrm{~mm}$ sieve) and significantly lower in plants from small sized seeds (passed through 2.8 $\mathrm{mm}$ sieve). It should be emphasized here that seed yield recorded for all seed sizes in the present study was very low. This could be attributed to the low rainfall during the period of investigation.

Seed size as an important indicator of seed quality was also found to affects the composition of air dried groundnut seeds. Harvested seeds grown from large seed size had significantly highest percentage moisture, ash, fibre and carbohydrate when compared to seeds harvested from plants grown from medium and small seed sizes. The relatively high moisture content of seeds harvested from large seeds may be a disadvantage in terms of storability or shelf life. These seeds therefore require care during storage as they would be prone to deterioration (Atasie et al. 2009; Kwenin 2011). In spite of this low shelf, the seeds could be a better source of roughage, minerals and energy due to of high fibre, ash and carbohydrate concentration. Diets rich in fibres have been found to eliminate problem of constipation and prevention of diseases of colon such as piles, appendicitis and cancer (Atasie et al. 2009). The seeds derived from planting small seed size had high protein and fat concentration. This high protein concentration could make the seeds a better food supplement for livestock feeds (Olayinka, Etejere 2013). Also, high oil concentration make the seeds a suitable nutrient that can improve energy status of man and animals (Ayoola et al. 2012). The values recorded for seeds derived from plants grown from medium seed size were found to be itnermediate to that from large and small sized seeds.

The results of this study demonstrated that planting of large seed improved growth and yield and resulted in produced seeds that had relatively high fibre, ash and carbohydrate. However such seeds might have a low shelf life because of higher moisture content. Small seed size was associated with lowest biological yield. However, plants grwon from small seeds produced seed with high protein and fat, and could be useful as food supplement for livestock feeds as well as improving energy status of man and animals.

\section{Acknowledgements}

Dr. B.U. Olyinka designed the experiment in terms of methodology and performed collection of data, presentation of results and discussion. Miss Sherifat Omolabake Owodeyi worked alongside the first author to collect the data and performed the analysis of composition of the seeds. Prof.E.O. Etejere provided the procedure for designation of the seed into three different sizes. He worked with the corresponding author to develop the literature review, presentation of results as well as discussion aspects of the work.

\section{References}

Adebisi M.A. 2004. Variation, stability and correlation studies in seed quality and yield components of sesame (Sesamum indicum L.). Ph.D. Thesis, University of Agriculture, Abeokuta, Nigeria.

Adebisi M.A., Kehinde T.O., Ajala M.O., Olowu E.F., Rasaki S. 2011. Assessment of seed quality and potential longevity in elite tropical soybean (Glycine max L.) Merrill grown in Southwestern Nigeria. Niger. Agric. J. 42: 94-103.

Adebisi M.A., Kehinde T.O., Salau A.W., Okesola L.A., Porbeni J.B.O., Esuruoso A.O., Oyekale K.O. 2013. Influence of different seed size fractions on seed germination, seedling emergence and seed yield characters in tropical soybean (Glycine max L. Merrill). Int. J. Agric. Res. 8: 26-33.

AOAC. 2000. Official Methods of Analysis. 17 $7^{\text {th }}$ Edition. Vol. 1. Association of Official Analytical Chemists. Inc., Maryland, USA.

Ayoola P.B., Adeyeye A., Onawumi O.O. 2012. Chemical evaluation of food value of groundnut (Arachis hypogaea) seeds. Amer. J. Food Nutr. 2: 55-57.

Ahirwar J.R. 2012. Effect of seed size and weight on seed germination of Alangium lamarckii Akola. Indian Res. J. Recent Sci. 1: 320-322.

Ambika S., Manomai V., Somasundaram G. 2014. Review on effect of seed size on seedling vigour and seed yield. Res. J. Sci. 7: 31-38.

Atasie V.N., Akinhanmi T.F., Ojiodu C.C. 2009. Proximate analysis and physico chemical properties of groundnut (Arachis hypogaea L). Pakistan J. Nutr. 8: 194-197.

Combs J., Hall D.O. 1982. Techniques in Bioproductivity and Photosynthesis. Pergamon Press, Oxford.

Hojjat S.S. 2011. Effect of seed size on germination and seedling growth of some lentil genotypes (Lens culnaris Medik.). Int. J. Agric. Crop Sci. 3: 1-5.

Jerlin R., Vadivelu K.K. 2004. Effect of fertilizer application in nursery for elite seedling production of Pungam (Pongamia pinnata L. Picrre). J. Trop. Agric. Res. Ext. 7: 69-71.

Kozlowski T.K. 1972. Seed Biology. Academic Press, NewYork and London.

Kewenin W.K.J, Wolli M., Dzomeku B.M 2011. Assessing the nutritional value of some African vegetables in Ghana. J. Animal Plant Sci. 10: 1300-1305.

Nagaraju S. 2001. Influence of seed size and treatments on seed yield and seed quality of sunflower cv. Morden. M.Sc. Thesis, University of Agricultural Sciences, Dharwad, Karnataka, India.

Nerson, H. 2002. Relationship between plant density and fruit and seed production in muskmelon. J. Am. Soc. Hort. Sci. 127: 855-859. 
Olayinka B.U., Etejere E.O. 2013. Influence of weed management strategies on proximate composition of two varieties of groundnut (Arachis hypogaea L.). Ann. Food Sci. Technol. 14: 286-293.

Ries S.K., Everson E.H. .1973. Protein content and seed size relationships with seedling vigor of wheat cultivars. Agron. J. 65: 884-886.

Roy S.K.S., Hamid A., Miah M.G., Hashem A. 1996. Seed size variation and its effects on germination and seedling vigour in rice. J. Agron. Crop Sci. 176: 79-82.

Sulochanamma B.N., Reddy Y.T. 2007. Effect of seed size on growth and yield of rainfed groundnut. Legume Res. 30: 33-36.

Steel R.G.D., Torrie J.H., Deekey D.A. 1997. Principles and procedures of statistics: A biometrical approach. $3^{\text {rd }}$ ed..McGraw Hill Book, New York.

Tawaha A.M., Turk M.A. 2004. Field pea seeding management for semi-arid mediterranean conditions. J. Agron. Crop Sci. 190: 86-92.

Vishvanath K., Kalappa V.P., Prasad S.R. 2006. Standardization of screen sizes for French bean seed processing. Seed Res. 34: 77-81. 